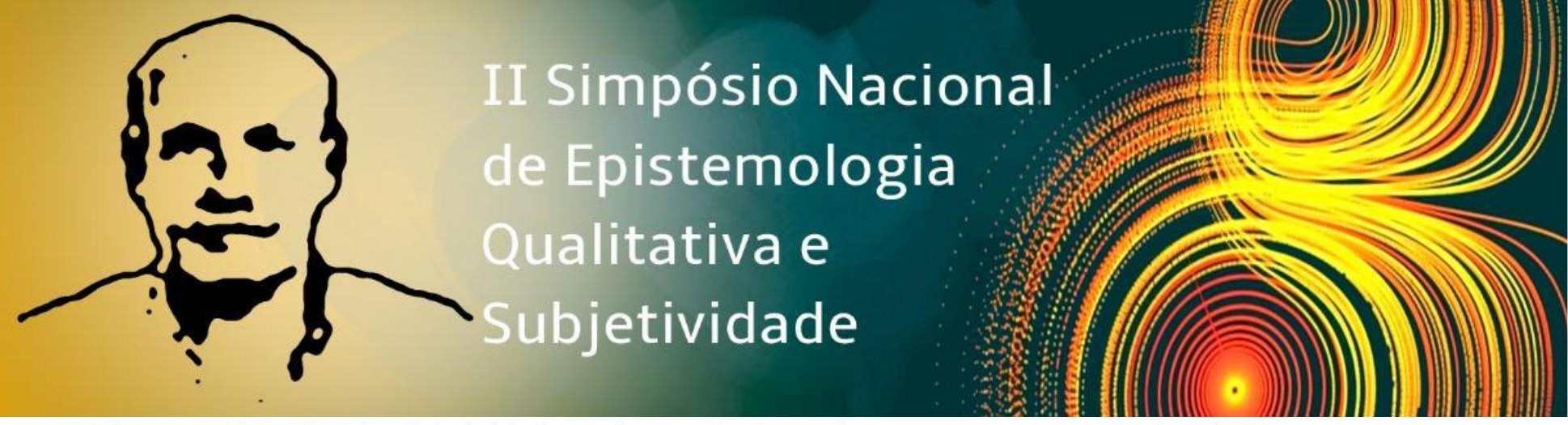

Eixo temático: 6 - A subjetividade na formação de professores e outros profissionais.

\title{
A Aprendizagem do Professor no Contexto da Ação Pedagógica
}

Valdívia de Lima Pires Egler, Universidade de Brasília, eglerval@gmail.com Albertina Mitjáns Martínez, Universidade de Brasília, amitjans49@gmail.com

\section{Resumo}

Apesar do interesse crescente nas pesquisas pela aprendizagem de professores na ação pedagógica, constata-se a necessidade de compreensões mais aprofundadas sobre o que e como o professor aprende neste contexto. Nesta perspectiva, o presente trabalho refere-se a uma pesquisa de doutorado em andamento que tem por objetivo compreender a configuração subjetiva da ação de aprender do professor na ação pedagógica e sua expressão em aprendizagens específicas. Fundamentamo-nos teoricamente na Teoria da Subjetividade (GONZÁLEZ REY, 2003; GONZÁLEZ REY; MITJÁNS MARTÍNEZ, 2017; MITJÁNS MARTÍNEZ; GONZÁLEZ REY, 2017), perspectiva que concebe a aprendizagem como processo que envolve o aprendiz em sua condição subjetiva e não apenas em suas funções intelectuais, enfatizando-se o caráter produtivo deste processo. Com base na Epistemologia Qualitativa e na Metodologia Construtivo-Interpretativa (GONZÁLEZ REY, 1997; GONZÁLEZ REY; MITJÁNS MARTÍNEZ, 2017) a pesquisa tem como participantes três professoras da educação básica da rede pública de educação, a partir da qual apresentamos um dos casos em estudo. Os instrumentos de pesquisa utilizados são as dinâmicas conversacionais; observação do cotidiano escolar; documentação pedagógica; análise de casos de ensino; análise documental de registros da ação pedagógica; redação; complemento de frases. As análises construtivo-interpretativas da pesquisadora, até o momento, possibilitam compreender que a ação pedagógica é um processo que se configura subjetivamente pela professora no decorrer desta experiência, relacionando-se à expressão de aprendizagens neste contexto. $\mathrm{O}$ caso estudado vem demonstrando que este processo se configura pelas produções subjetivas da professora acerca das necessidades que se apresentam na ação pedagógica e sobre estudantes específicos; por conhecimentos e recursos desenvolvidos anteriormente em outros contextos e como são subjetivados no momento da ação pedagógica, bem como por sentidos subjetivos 


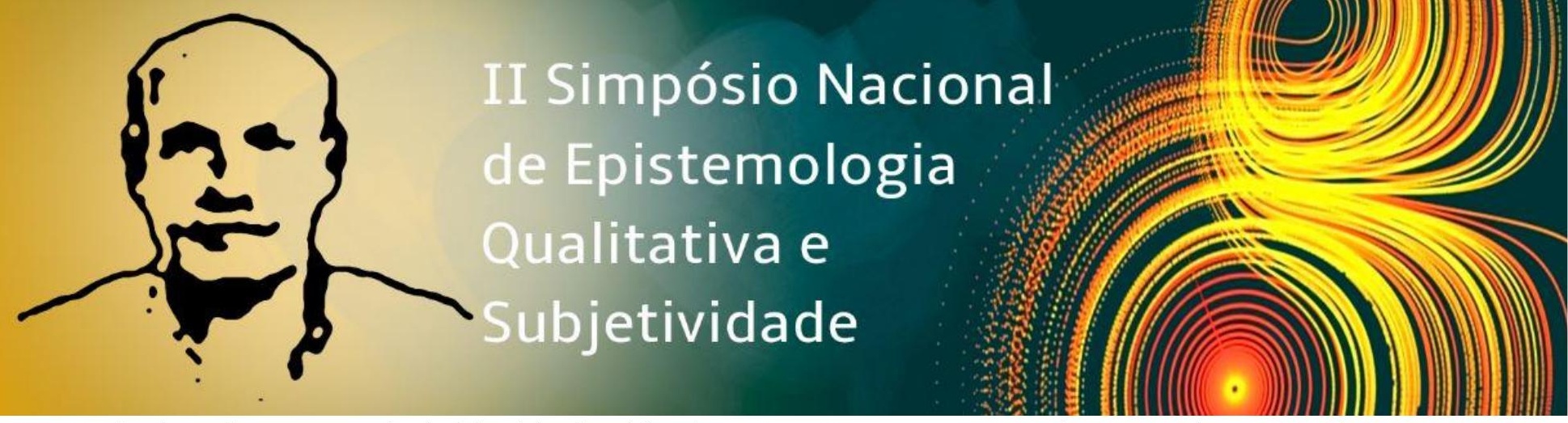

relacionados a sua própria história de vida. Apresenta-se nesta perspectiva a seguinte questão: quais as relações entre a configuração subjetiva da ação pedagógica e a expressão de aprendizagens, pelo professor, neste processo?

Palavras chave: Aprendizagem - Professor - Ação pedagógica.

\section{Referências}

GONZÁLEZ REY, F. Epistemologia Qualitativa y Subjetividad. Playa, Ciudad de La Habana. Editorial Pueblo y Educación, 1997.

Sujeito e Subjetividade. São Paulo: Pioneira Thompson Learning, 2003.

; MITJÁNS MARTÍNEZ, A. Subjetividade: teoria, epistemologia e método.

Campinas: Editora Alínea, 2017.

MITJÁNS MARTÍNEZ, A.; GONZÁLEZ REY, F.L. Psicologia, Educação e Aprendizagem

Escolar: avançando na contribuição da leitura cultural-histórica. São Paulo: Cortez, 2017. 